\title{
Self-narration and agency as interactive achievements: A sociocultural and interactionist analysis of migrant women's stories in a language learning setting
}

\author{
Nathalie Muller Mirza*, Marcelo Dos Santos Mamed \\ Department of Psychology, Faculty of Social and Political Sciences, University of Lausanne, Lausanne, Switzerland
}

\section{A R T I C L E I N F O}

\section{Keywords:}

Migration

Narrative

Identity

Social interaction

Agency

Language learning

\begin{abstract}
A B S T R A C T
Migration is commonly seen as disrupting individuals' sense of continuity and agency. In current research on adult identity development, (self-)narratives are regarded as a means of making sense of self. In a study aiming at examining how identity processes were managed and produced during self-narration by immigrant women in a language learning setting, we combined an interactionist methodology with a sociocultural and dialogical perspective. Data were gathered throughout an intervention designed to encourage participants to put their personal experiences of migration into words in narrative form. Verbal interactions were analysed to identify 1) narrative discursive units, 2) processes of narrative co-construction, 3) agentic relationships in and on the narratives. Results, illustrated with various excerpts, showed that self-narratives arose from dynamic interactions in which participants displayed discursive skills in negotiating status and instructions, supported the cognitive and affective work of narrating in a foreign language, and constructed agency that challenged the poor immigrant woman image. The potential of analysing the interactional processes of co-constructing self-narratives is discussed in terms of its theoretical and methodological contributions in the field of identity research.
\end{abstract}

\section{Introduction}

Personal identity emerges from a delicate balance between rupture and stability. Migration can be conceived of as an experience that impacts individuals' sense of continuity and may alter their sense of agency. As a result of breakdowns leading them to leave their familiar environment, immigrant adults have to deal with a new social and physical environment, a social position to assume, sometimes little income security in their host country and often a new language to learn. In Switzerland, as in other European countries, immigrant women attempting to enter the labour market frequently have to contend with the double stereotype of foreigners as invaders and women as lacking skills, even though a large proportion of migrant women in Switzerland are well educated (Kofler, Fankhauser, \& Zweifel, 2009).

A current research trend in social psychology and education highlights the potential of narration as a cultural means of making sense of experience and producing agency (Daiute \& Kreniske, 2016). When daily routine has been interrupted, narration - the human ability to tell stories - and in particular self-narration is considered to be a powerful psychological instrument that plays an important role in the processes of identity construction and reconfiguration (Bruner, 2003; De Abreu, O'Sullivan-Lago, \& Hale, 2012;

\footnotetext{
* Corresponding author at: Department of Psychology, Faculty of Social and Political Sciences, University of Lausanne, CH - 1015 Lausanne, Switzerland.

E-mail addresses: Nathalie.mullermirza@unil.ch (N. Muller Mirza), Marcelo.dossantosmamed@unil.ch (M. Dos Santos Mamed).
} 
Zittoun, Gillespie, Cornish, \& Aveling, 2008). Narration can also be used in intervention settings as a means of giving a silent part of the population a voice.

In the present study, we aimed at examining how identity processes were managed and produced during the activity of selfnarration by immigrant women within the framework of a research-intervention. The setting was designed to support the selfnarrative abilities of migrant women arriving in Switzerland, and develop their sense of agency.

We adopted a sociocultural approach in psychology and education in which self-narratives are analysed as polyphonic texts in which the narrators orchestrate various voices, thus positioning themselves in a complex landscape made up of contradictions, tensions, and dilemmas (Bhatia \& Ram, 2004; Grossen, 2015; Hermans, 2001). We referred also to an interactionist perspective which considers that psychological processes such as learning or sense of identity do not occur in the mind of individuals but are embedded in the "procedural infrastructure" (Schegloff, 1992, p. 134) of social interaction (Pekarek Doehler, 2013). In this perspective, we sought to describe narrative as a collective achievement and thereby to understand how individuals construct and negotiate the activity of narration in interactions. We therefore combined a sociocultural approach with an interactionist approach (Bamberg, 2004; Van Dijk, 1995; Garfinkel, 1967; Pekarek Doehler, 2013), in order to examine the way resources are mobilized by the interlocutors, not only in the story they are telling, but also in the social activity of narration. We hypothesized that a fine-grained analysis of the use of language and interactional organization - the turn-taking and question-and-answer procedures people use to organize the task of narrating their story - can yield valuable information on agency and the processes of achieving identity in social interactions.

More specifically, we sought to analyse the interactive production of narratives during a collective session by three women recounting their experience of arriving in Switzerland. In contrast to previous studies that had analysed the content of the narratives or the way individuals positioned themselves in their self-narratives, we were interested in the process of identity-in-the-making.

\section{Identity, agency and narratives}

Owing to increased globalization, massive migratory flows and border crossings, migrants' identity and acculturation are an important object of study in human development (Hermans \& Kempen, 1998). For the purpose of our study, we referred to authors who have focused on the ongoing process - made up of changes, contradictions, tensions and asymmetries - whereby migrants are active agents in the transformation of social networks and cultural practices (Bhatia \& Ram, 2001; Hermans, 2001; Rosa \& Tavares, 2013). This perspective allowed us to avoid the problem of presupposing clearcut cultures and identities, as each individual belongs to a plurality of cultural communities, and identities may change over time and according to cultural belonging. The notion of the hybridity and porousness of cultures and identities may more accurately reflect the psychosocial experience of multiple and changing memberships (Greco Morasso \& Zittoun, 2014).

From this perspective, sociocultural psychologists have emphasised the central role of language, not only as a vehicle for conveying messages but also as a means of allowing personal experience and development to be reorganized. Vygotsky was fascinated with how cultural semiotic systems, as cultural-historical products learned through social interactions, gave rise to consciousness, and introduced the possibility of self-regulation (Vygotsky, 1978; Wertsch, 1985). Through the historically and culturally situated use of signs, humans are able to affect both other people's and their own psychological functions. These cultural forms play a central role in the development of identity and agency (Holland \& Valsiner, 1988; Mäkitalo, 2016; Rajala, Martin, \& Kumpulainen, 2016). Among the cultural symbolic systems of signs, narration is regarded as a particularly powerful mediational discursive tool in acts of identification and positioning (Wertsch, 2000). Bruner (1990, 2003), as a cultural psychologist, argued that we organize human experience and memory through various forms of narratives (stories, myths, etc.) and in particular through self-narratives - these narratives in which the narrator and the central figure in the narrative are the same - that he defines as "an instrument of mind in the construction of reality" (Bruner, 2003, p. 6). As cultural tools, they allow individuals to construct and reconstruct their self: "Eventually the culturally shaped cognitive and linguistic processes that guide the self-telling of life narratives achieve the power to structure perceptual experience, to organize memory, to segment and purpose-build the very 'events' of a life. In the end, we become the autobiographical narratives by which we 'tell about' our lives" (Bruner, 2006, p. 694).

In this perspective, the study of self-narration seems particularly relevant for understanding the formation of identities, and it is therefore a crucial object of research in identity research (Bamberg, 2011). Of the many ways in which narratives can be construed as a research object, an interactionist perspective seems heuristic. By highlighting the role of language in world-making and self-making, interactionists have paved the way for a recognition of the situated nature of identity: identity categories are locally constructed as discursive resources and emerge within sequences of talk (Antaki \& Widdicombe, 1998; Goodwin, 1984). Authors in this field provide an endogenous perspective on social actions, focusing on "the range of procedures and considerations by means of which the ordinary members of society make sense of, find their way about it, and act on the circumstances in which they find themselves" (Heritage, 2013, p. 4).

At the methodological level, this approach implies treating the narrative as a verbal act that is performed in a situated, interactional context (Bamberg, 2011; Goodwin, 2015). Its role in identity processes cannot be reduced to the messages it conveys. Instead, it is important to consider the local interactional context in which such narrative units emerge and to study discursive resources not as pre-established, but as interactively achieved. 


\section{Methodology}

\subsection{The context of data generation}

We collected the data during a French-language course run by a voluntary organization that seeks to support the integration of immigrant women in a city located in the French-speaking part of Switzerland. The teacher in charge of this course aimed at supporting the participants (seven or so women from countries all over the world: Italy, Lebanon, Russia, Turkey, Brazil, Colombia, Ukraine) with Level A2 French as a foreign language. ${ }^{1}$ Herself interested in the topics of learning language, migration and narrative, she agreed to free up enough time for a brief intervention. The latter's general objective was to produce a narrative in French in which the story of the participants' arrival in Switzerland, the difficulties they had faced and the resources they had mobilized were set out in a collective setting. After a discussion with the teacher about our aims and the envisioned organization of the intervention (the main topics discussed, the role of each of us, etc.), we asked the participants their agreement to participate. Two main objectives were presented: we told that we aimed not only at better understanding how people who are coming in Switzerland from abroad face difficulties and use resources and competencies to overcome challenges but also at providing them an opportunity to speak French and to tell their own personal story in a benevolent and confidential frame. We committed to provide a small book with the stories we told in this collective setting at the end of the third session. We ensured that the participants well understood that their participation was on a voluntary basis and that recorded data will be anonymised and used only for a research purpose. To facilitate this discursive production, which entailed very intimate and emotional dimensions, we devised a sequence of four weekly sessions, each lasting around $90 \mathrm{~min}$.

In the first session, four researchers in sociocultural psychology, including the first author (who led the intervention) and second author, presented the main objectives and steps of the intervention. The participants (and researchers) were then each invited to tell a tale to the group, drawing on the myths and legends they had been told as children. The researchers highlighted the main structure of these tales, in order to show their specificities but also their universal and shared features. They reminded the women of the characteristics of the narrative archetype hero's journey, where a hero has to leave his or her community, in order to respond to a Question and solve a Problem. The hero has some extraordinary experiences in distant places, and returns home with an important message to tell that transcends his or her personal life. Here, the researchers drew a parallel between the characteristics of this archetypal tale and the trajectory the participants had probably followed as immigrants.

In the second session, the researchers introduced the women to one of the most well-known Swiss tales: Heidi, a work of fiction written in 1881 by Johanna Spyri. This novel (translated into many languages and made into more than twenty movies and cartoons around the world) recounts the life of a young girl who spends the first part of her childhood living happily in the Swiss Alps with her grandfather. When she is 8 , she has to leave her beloved mountains and become a playmate to Clara, a girl regarded as an invalid who lives in a big city, abroad, in a foreign country. Heidi finds it hard to adapt to her new environment and becomes homesick. However, a strong friendship gradually grows between the two girls: Carla teaches Heidi how to read and Heidi helps Carla to get stronger and trust in her own strength, and ultimately to walk again. Participants watched and discussed several short sequences of the 1952 movie of the same name directed by Luigi Comencini. These sequences were chosen because they addressed topics that we regarded as being close to the participants' understanding of migration. They were intended to serve as a point of departure for discussions about migration as an experience of suffering but also of possible personal and social development.

The third session was devoted to the production of self-narratives. Participants were invited to recount their own experience of migration when they arrived in the new world represented by Switzerland, with reference to the Heidi movie.

The fourth and final session was dedicated to reading and discussing a collective narrative that was composed by the researchers from the data contained in the personal stories told by the women. It was then printed in booklet form, complete with pictures of the participants, and shared with them. The intervention ended with a meal featuring dishes prepared by the participants and researchers.

As we said, the data analysed in this paper concern part of the third session devoted to the production of narratives. Relative to Heidi's experience, participants were invited to respond to the following question, posed by Nathalie, the first author: "What happened when you arrived in your new world?", and then reformulated by Tracy, their teacher: "What happened in relation to what you had experienced in your own country? What were the things that surprised you, and what difficulties did you have?"

We chose here to focus on narratives produced by three women who actively participated to the discussion: Kaja, ${ }^{2}$ Iliana and Leila. The three narratives featured reflect the main types of trajectories followed by migrant women arriving in Switzerland, be it for political, economical or family reasons: ${ }^{3}$

- Kaja is around 35 years old and comes from Kurdistan, in Turkey. She moved to Switzerland for political reasons. She used to be an accounting officer. She is the mother of two children;

- Iliana is a young Italian artist around 30 years old. She decided, together with the father of her two children, to leave Italy to look for more stable economic conditions and a better life;

\footnotetext{
${ }^{1}$ According to the European Language Portfolio (ELP).

${ }^{2}$ All the names of the participants are pseudonyms.

${ }^{3}$ We did not gather any further personal data, as we wished to respect the spirit of the women's association, which does not collect information about its members' personal trajectories. All the information we received was spontaneously provided by the women in the course of the sessions.
} 
- Leila is around 30 years old as well, and was born in Lebanon. She is an educated young woman and was economically independent in her home country. She reluctantly left Lebanon and her family so that her husband could take up a new career opportunity in Switzerland.

The session lasted just over $75 \mathrm{~min}$. It was recorded and transcribed following the norms developed by ICOR group in the laboratory ICAR from University of Lyon, France (ICAR, 2013) (see Appendix A). The extracts were transcribed by the second author and translated into English by a native bilingual speaker who carefully tried to render the grammatical characteristics of the language spoken by non-native participants.

Before describing our research questions and analytic methods, we need to emphasise that the data were generated during an interaction between expert (teacher and researchers) and novice (participants) French-language speakers. From the latter's perspective, the activity of telling their own story was quite challenging, as considerable implicit know-how is required regarding discourse organization, the interactional space, and topic construction. In line with researchers in the field of language acquisition, we nonetheless regarded the nonexpert speakers as capable agents who could use complex methods and systematic procedures to engage in interactions and reduce asymmetries in talk-in-interaction (Gardner \& Wagner, 2004; Pekarek Doehler, 2006).

We focused on the interactional achievement of identity through utterance management and explored the strategies participants used in this activity. The focus was therefore on how participants used their linguistic resources to construct self-narratives in interaction, by means of what Pekarek Doehler (2006) called competence-in-action.

\subsection{Research questions and methodological framework}

Considering conversation as a social action in which people construct, establish norms and expectations, and negotiate their identities, our methodological approach focused on the conversational procedures of the speakers' self-narratives, and the way they positioned themselves through language in relation to the world, other people and themselves. We used this perspective to track how the participants performed and interpreted the action of self-narrating through a collective construction process.

Our analysis of the data was guided by three research questions, all relating to the interactive achievement of identity.

The first question focused on the activity of self-narrating: how did the participants discursively and collectively frame their selfnarratives? Which discursive actions were performed by the speakers when recounting their self-narratives? What procedures were used? And how were these procedures collectively negotiated?

In order to examine this point, we began by identifying what we called "narrative discursive units" (NDUs) in the conversation. In this perspective, we followed Quasthoff who claimed that a self-narrative can be associated with a discourse unit [DU], characterized by chunks of conversation clearly marked as being different from the surrounding turn-by-turn talk. In this perspective, an NDU entails specificities at the level of both form and content. At the content level, an NDU generally refers to a sequence of temporally structured events that happened in the past, in which the narrator was involved in the role of agent or observer. The narrator is therefore presented as having special access to a knowledge of her past experience, which she puts into words and may evaluate. At the form level, the sequence is generally opened interactively by a question intended to elicit a response. In their descriptions of conversational situations, proponents of conversation analysis (Schegloff, 1968; Schegloff, 1972; Schegloff \& Sacks, 1973) refer to these functional exchanges as adjacency pairs (APs). The construction of the response allows the speaker to hold the floor most of the time until the NDU is closed (Bamberg, 1997). The adjacency pairs also allow to open a discursive space to be constructed through a work of topicalization, that is, the co-construction of internal semantic coherence around a particular theme. In narration, topicalization processes can be regarded as being linked to a work of dramatization, marking the disturbance of what was expected by the protagonists (Gülich \& Quasthoff, 1985). We therefore began our analysis of the corpus by identifying NDUs and the way they were framed by APs, and constructed through a work of topicalization and dramatization.

The second question aimed at examining through which interactional processes did their self-narratives emerge during the whole intervention. We therefore focused on the interactive co-construction of the narratives throughout the intervention. Here, we were interested in the way the topics evoked by the narrators echoed each other across the four sessions.

The third question focused on agency: which agentic relationships were displayed during the process of self-narration? On the basis of researchers adopting a sociocultural and interactionist perspective, we here focused the analysis on three main discursive indicators of agency. We analysed how the self of the narrators was played out in terms of agentic relationships, both in the narrative (relationship between the main actor and the world in the sequence of narrated events) and on the narrative (narrator's reflexive stance towards what is being recounted). We distinguished between a "being positioned orientation" and a more "agentic orientation" (Bamberg, 1997). In a first phase, we choose to analyse the action verbs used by the narrators and their active or passive forms. We looked at how the relationship between the actor and her environment was portrayed, whether the actor was presented as an agent who acted intentionally or whether she was acted upon by others and by events. We were also interested in the use of a "genericity" modality of describing the events ("it is", "one does", etc.), that indicates an absence of the narrator from the events being recounted (Muller Mirza, Grossen, de Diesbach-Dolder, \& Nicollin, 2014). We identified a further indicator of agency: the way the narrators commented on and made reflexive remarks about their own discourse. 


\section{Results}

\subsection{Narrative discourse units: an interactional achievement}

Based on the definition of an NDU (temporally structured sequence of past events in which the narrator was involved as an agent or observer), we began by identifying three main NDUs in the session's transcripts, produced by Kaja, Iliana and Leila. In order to track how these were interactively completed, we focused our analysis on the opening and closing procedures, and the work of topicalization and dramatization.

Regarding the opening phase, we found that all three NDUs were framed by an opening - and a closing - activity that was jointly produced by participants.

In the following example (Excerpt 1), we can see how Leila's narrative was opened. The extract began when Iliana had just finished her talk. After a long silence ( $4 \mathrm{~s})$, Marcelo selected Leila as a speaker:

Excerpt 1. ${ }^{4}$

\section{Excerpt $1^{4}$}

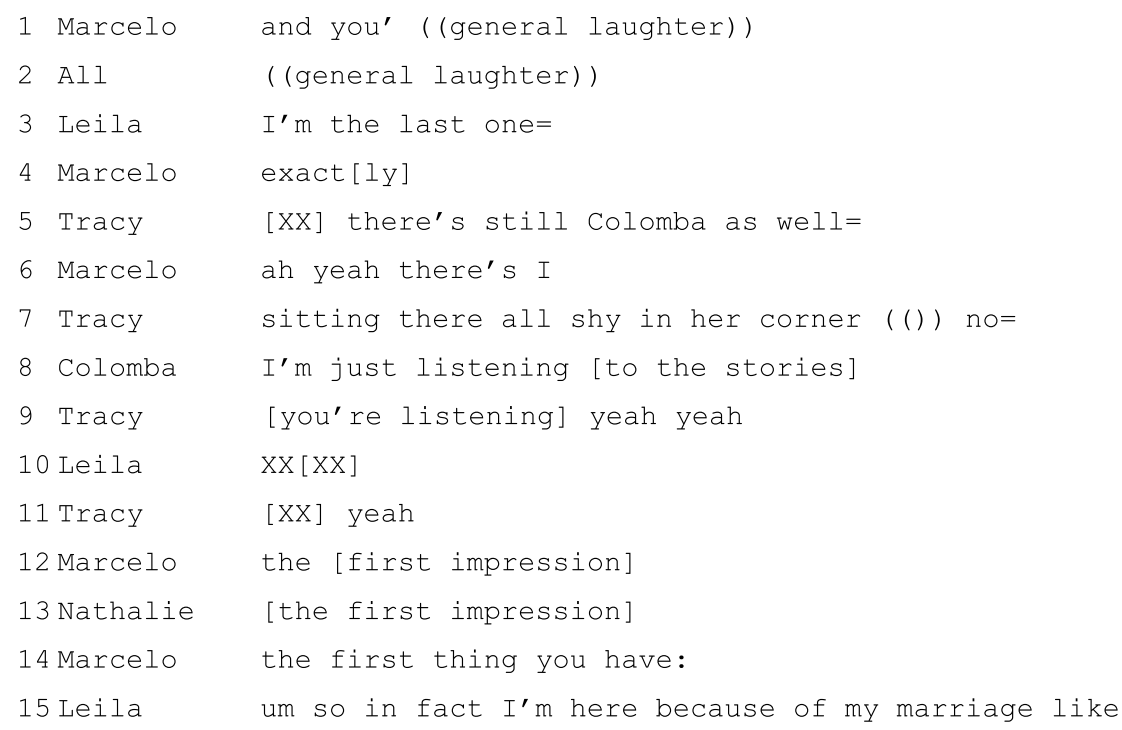

The first part of the AP (question-response) is elaborated within 15 speech turns (Ts). It begins with the other-selection of Leila by Marcelo, who asks the question "and you?", opening up a broad semantic space that derives its meaning from the previous turns. Leila's response takes the form of a justification, as though she interpreted the question as an evaluative remark (T3). Tracy reminds everyone that there is another participant - Colomba - who has not yet spoken (T5), but Colomba's turn confirms that Leila is to be the last speaker (T8). Marcelo and Nathalie (T12, 13, 14), taking on the role of guiding the interaction, recall the topic by referring to the "first impression". This introduction marks the beginning of the NDU, preparing the action of self-narration. In this sense, it functions as a preface to the NDU or an element preparing a longer and more complex turn taking, during which the participants negotiate issues related to the status of the interlocutors (who is asking questions, in which order, to whom, etc.) and the topic to be addressed.

The topicalization activity, another characteristic of an NDU, is well illustrated in the second example (Excerpt 2). This extract begins when Kaja had apparently finished to tell the story of her arrival in Switzerland. After a silence, Kaja is invited to take again the floor as a response to the question of Iliana.

\footnotetext{
${ }^{4}$ We decided to renumber the speech turns for each excerpt, as some parts of the session transcript were missing. The excerpts in the original French language are provided in Appendix B.
} 


\section{Excerpt 2.}

\section{Excerpt 2}

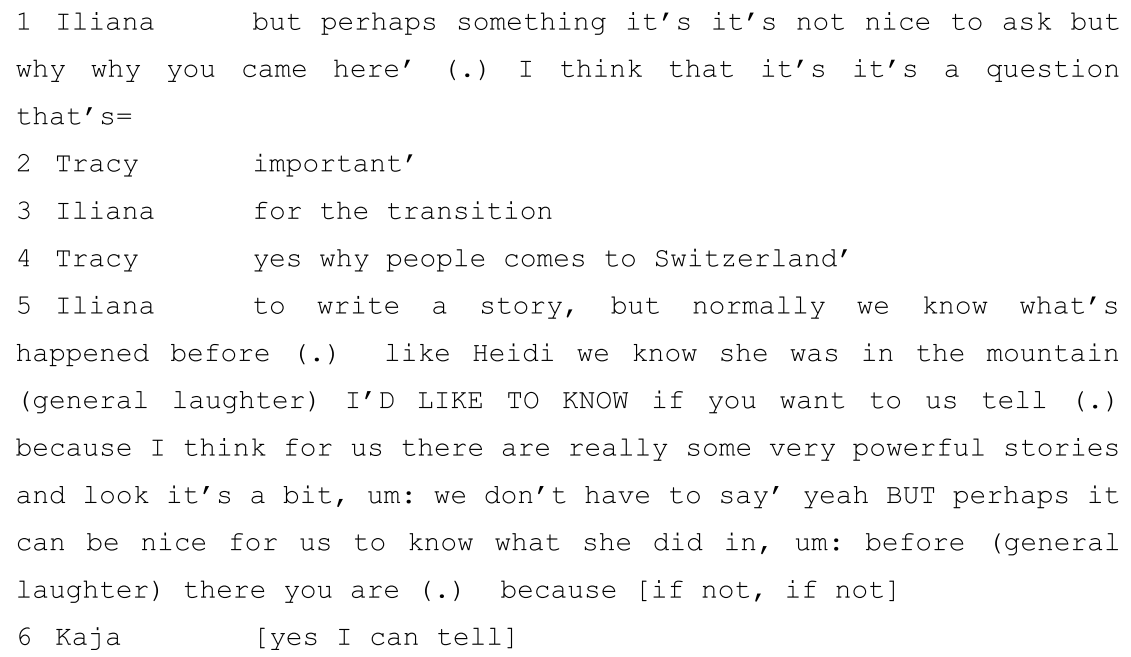

Kaja's narrative and the subsequent topicalization result from a collective work of adjustment guided by Iliana, with input from Tracy. In T1, Iliana's opening intervention implies that Kaja's narrative needs to be reorganized (introduced by a but signalling a break with previous turns). With Tracy's help (T2, T4), Iliana offers Kaja a new narrative instruction: rather than recounting what she faced on her arrival in Switzerland, she is asked to explain why she came to Switzerland in the first place. Therefore, Iliana's intervention actively contributes to the new topicalization and radically changes the course of the conversation. The question to be answered is no longer "what happened to you when you arrived in Switzerland?", but "why did you come to Switzerland?" Interestingly, as a discursive resource, she uses an element that is collectively shared - the story of Heidi (T5). In T6, Kaja starts her narrative following the interactively established instructions and recalls the reasons why she decided to come to Switzerland.

The third excerpt illustrates the work of dramatization which is another central characteristic of an NDU. This extract follows the interaction between Kaja and Iliana (Excerpt 2). The marking of the "disturbance" is very quickly exposed, as illustrated in the following excerpt.

\section{Excerpt 3.}

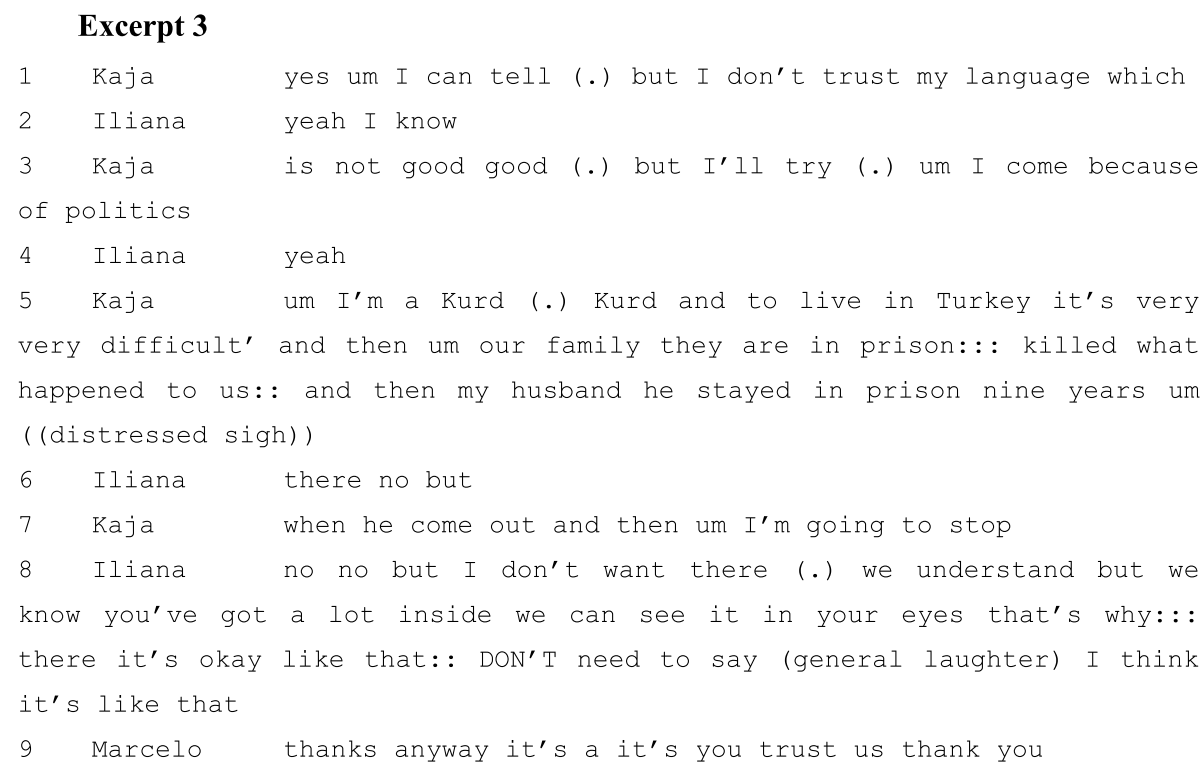


From T1 onwards, Kaja, who has agreed to the new task ("yes um I can tell"), introduces her narrative, recalling the reasons why she decided to come to Switzerland and the dramatic situation she lived through with her family - some of her relatives were killed and her husband, who was imprisoned for nine long years. This sequence is organized around numerous temporal indicators ("and then", "He stayed nine years", "I worked", "as [when] I come here [here in Switzerland]", etc.), as she recounts a sequence of past events. This extract is characterized by Kaja's use of emotional devices in the telling of her story, to refer not only to the events she is narrating, but also to the activity of narration. To describe her life in Turkey as a member of the Kurdish community, she uses a set of adjectives and verbs expressing negative feelings (T5). The emotions she expresses in her narrative affect the way she tells it. At one point, when she is recalling her husband's time in prison, she has to stop, as her voice is faltering, and she comments on what she is discursively doing ("um I'm going to stop"). At this point, Iliana adds "no no but I don't want there, we understand but", and justifies her first question, as she probably feels responsible for causing this emotional stress (T8).

We can draw three main observations from this initial analysis:

a) In this setting, NDUs can be seen as heterogeneous and dialogical spaces (Grossen, 2015), and are the result of a discursive activity that is interactively opened by means of a question-response AP. It takes the form of a preface that seems a necessary step before entering into the actual self-narrative, allowing the status of the interlocutors and the narrative instructions to be negotiated;

b) The participants were able to mobilize sophisticated discursive skills to produce self-narratives in which events referring to past experiences were described in temporal sequences, topics were constructed (e.g., difficulties related to language and organizing life in the new world, differences between the old and new countries),

c) The drama, the most important ingredient of any narrative, was put into words. Actually, NDUs here were made up of emotional features that were expressed by the narrators, and shared and supported by the other participants.

1.1. The interactive management of self-narratives throughout the session

The focus in this section is on the way the self-narratives were co-constructed across the four sessions. Three extracts are discussed, as they show the dialogical relations the interlocutors forged across the sessions.

In the first example (Excerpt 4), Kaja is finishing her self-narrative in which she explains how difficult it was to come to Switzerland with her two children, as her husband was still in prison in Turkey.

Excerpt 4.

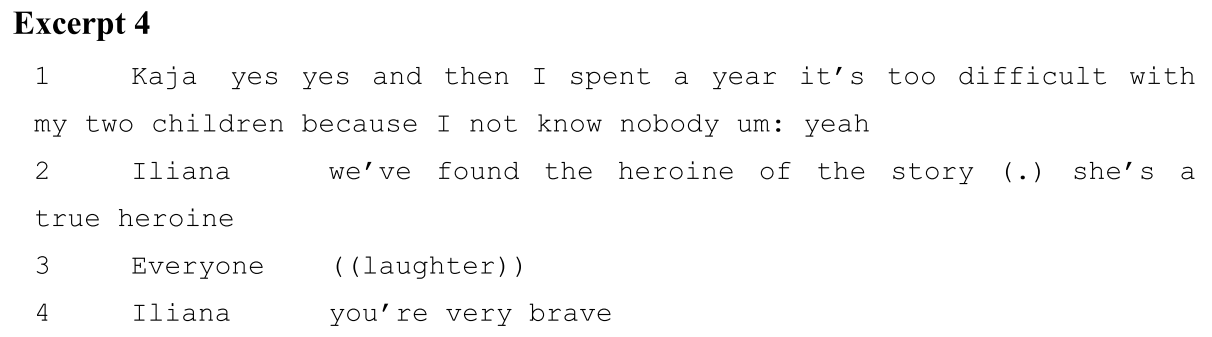

In T2, Iliana makes a statement identifying Kaja as a heroine. The use of this particular term is interesting, as it can be interpreted as both a (positive) assessment of Kaja's extraordinary trajectory, and a reference to a previous discussion the group had. During the first session, the participants discussed what the hero of a tale is and tried to define this figure using different examples. With her statement, Iliana therefore performs two social actions: 1) she suggests that because Kaja faced and resolved unusual difficulties, she can be seen as a particularly powerful person, far removed from the stereotype of a poor, weak immigrant; and 2) by referring to a previous discussion within the group, she reminds the participants that they are linked by their shared work of (re)defining their narratives and identities. This example illustrates how participants used the instructions they were given to organize their narratives, as well as the complex relations between actions, norms and context.

In the following two examples (Excerpts 5 and 6), Iliana and Leila both address the same topic: the cold climate in Switzerland. When asked by the researchers about their "first impression when they arrived in Switzerland", they both made references to the cold. This is hardly surprising, given that Switzerland is well known for its northern weather, and is often perceived of as being colder than the birth countries of immigrants from the South. However, it is interesting to observe how Iliana and Leila elaborated on the term coldness and which meanings were constructed around it. We see that the two women explicitly refer to each other, but in contrasting ways. 


\section{Excerpt 5.}

\section{Excerpt 5}

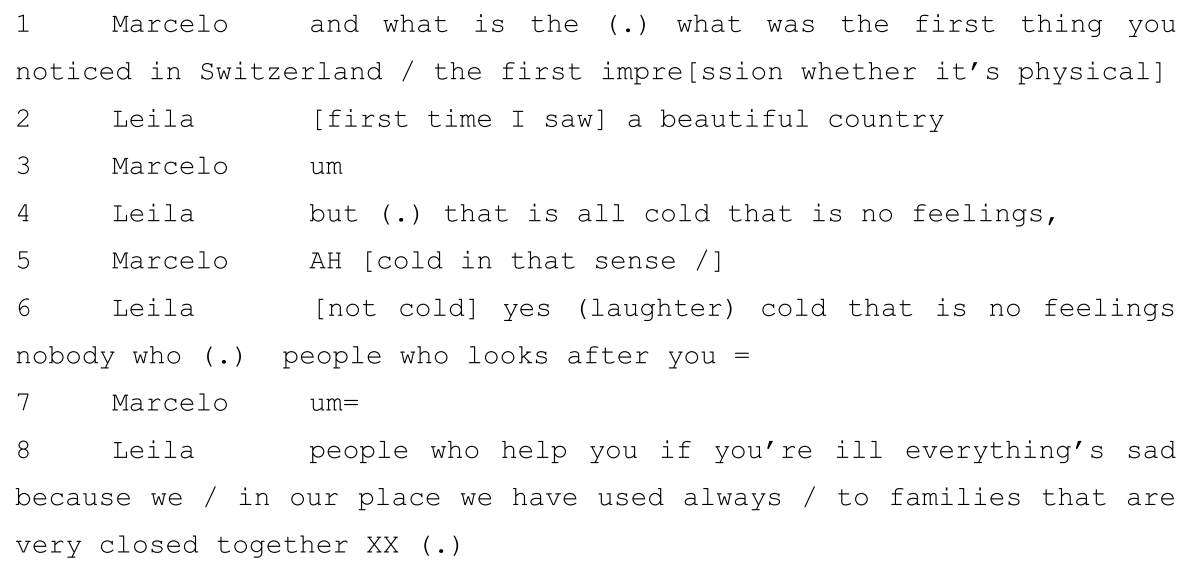

In T1, Marcelo takes on the role of guiding the conversation and steers the expected response ("the first impression") towards a semantic space of physical perception ("whether it's physical"). Leila's first response (T2, T4) is constructed around two categories: beauty ("I saw a beautiful country") and coldness ("cold") - categories she relates in a contrasting way, by means of a "but" (T4). In T4 and T6, Leila defines "cold" as a characteristic not of the weather, but of the social environment. The topic then shifts from a physical perception (as indicated in the question) to an affective one ("no feelings"). This shift allows Leila to continue describing her arrival, making a distinction between "in our place" and "in Switzerland", which entails a further distinction between solidarity ("people who help you") and sadness ("everything's sad").

Later on in the conversation, Iliana starts her own narrative, using the same descriptive device to respond to the researchers' question:

\section{Excerpt 6.}

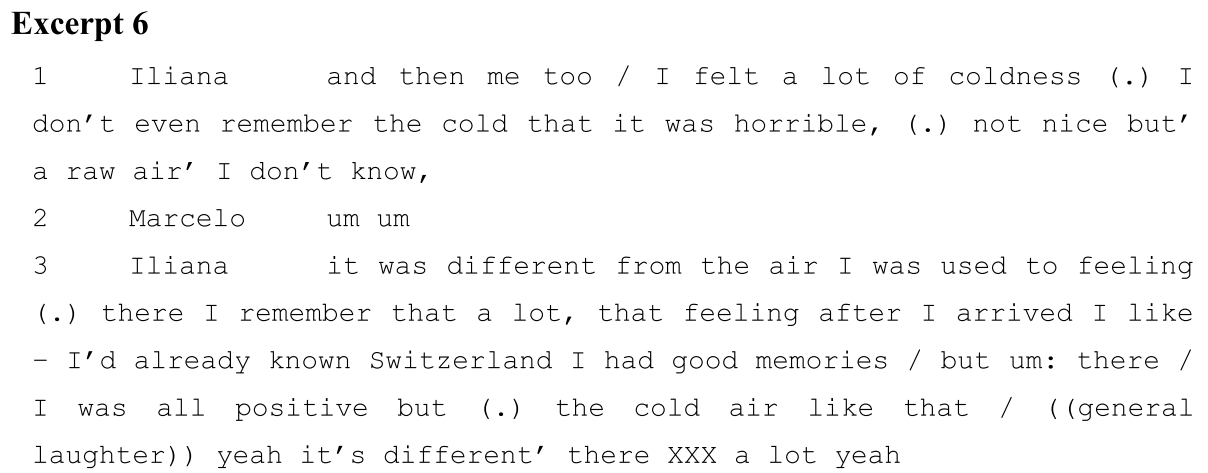

In T1, Iliana explicitly refers to Leila's narrative, saying that she too felt the coldness in Switzerland. However, she expresses another personal feeling that appears to contrast with Leila's ("I don't even remember the cold that it was horrible"), and constructs the meaning around coldness in terms of air and temperature conditions. She uses the same discursive device of comparing there (in my place) and here (in Switzerland), and elaborates on the differences, but unlike Leila, describes them not negatively but positively ("I was all positive").

We drew two main observations from this second analysis:

a) The processes of self-narrative construction involved a complex interactive work of adjustment and reference to each other's discourses, taking up the topics provided by the researchers and adjusting them to the ongoing conversation;

b) The resulting narratives were therefore woven through with different kinds of features, highlighting their co-constructive nature and the interactive abilities of the narrators.

1.2. Agentic relationships

In the third part of our analysis, we focused on two forms of agency: that of the actor in the self-narrative, and that of the narrator in the activity of narration. 
Remarkably, all three narrators produced agentic stories, in that the narrated events were related to theItelling the story. They presented themselves as actors who took the decisive actions in their lives, particularly during their migration. Let us take some examples extracted from the three NDUs.

In the Excerpt 7, Kaja describes her life when she was in Turkey.

\section{Excerpt 7.}

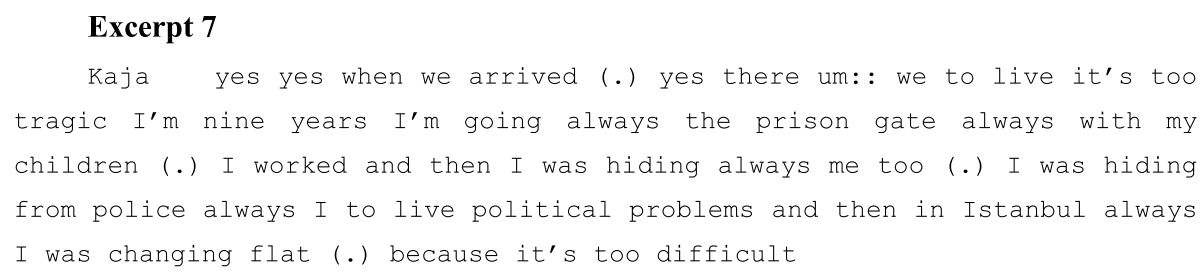

In Kaja's narrative, we can see that her NDU is mainly structured by verbs showing her determination ("I'm going", "I worked", "I was changing flat"...), even in extremely difficult times.

In her narrative, Iliana also constructed an agentic reality that is manifest through the use of vocabulary. In Excerpt 8 for instance, she tells the story of her own decision to leave her country, Italy, and the moment of her departure, when, alone with her two children, she loads all her possessions into her car and sets off on the long trek from South Italy up through this country and into Switzerland:

\section{Excerpt 8.}

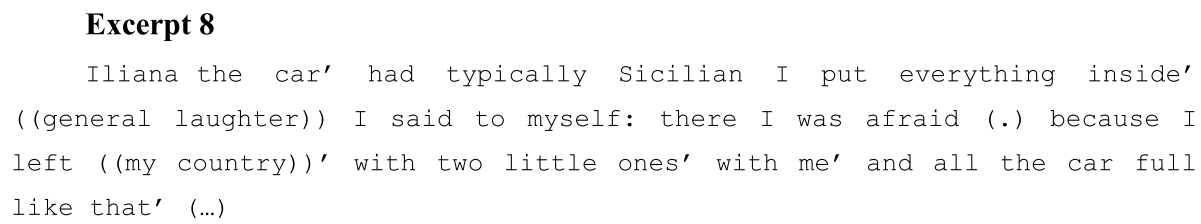

Leila was the participant who most strongly expressed her reluctance to leave her family, her country and, to some extent, the independence she enjoyed in Lebanon. However, in her narrative, she uses many active verbs, as it is illustrated by the following excerpt:

Excerpt 9.

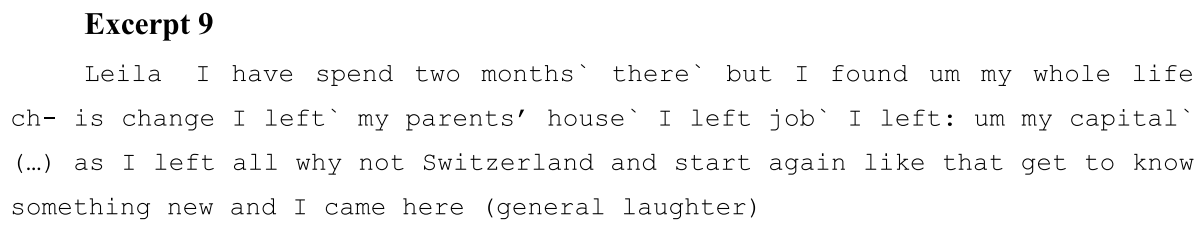

Generic accounts were also provided, in particular by Iliana and Kaja, who seemed to construct their narratives in two contrasting parts: on the one hand the world as it is ("there, that's the rule in Italy", "that's how it is", "it's hard", "to live in Turkey it's very very difficult", "it's too difficult", "it's not easy") and on the other hand, their own choices, the decisions they made and the actions they took.

When we analysed the way that identity and agency were generated, we also found that the participants, like any narrators, used reported (indirect) discourse in their self-narratives. Indirect discourse serves to make other people or voices present in the narrative and makes the boundaries between the speaker, the author and the party who actually assembles the words being spoken fussy (Goodwin, 2015). A husband or other family member who played an important role in the story could thus be summoned onto the narrative stage. 
As an illustration, Iliana recalls in Excerpt 10 the moment when her husband had alone to fly to Switzerland on his own and start a new life:

\section{Excerpt 10.}

\section{Excerpt 10}

Iliana I said *so you're ready* he said to me *yes ok* ((*change of tone)).

Interestingly, in two NDUs (produced by Iliana and Leila), indirect discourse was used to create an internal dialogue between the actor and narrator (e.g., "I said to myself *good luck* ((general laughter))", "I said *no I can't live there*"). In her work on migrant women, Greco Morasso (2013; Xenitidou \& Greco Morasso, 2013) showed that these types of internal dialogue can function as argumentative tools when individuals face decisive choices in their lives, indicating not only to their audience, but also to themselves at the point of narration, the cognitive processes that had to be engaged during a difficult period in their past.

Our analysis also revealed explicit traces of the reflexive activity displayed by the narrators as they told their stories. Kaja in particular, probably in part because of her feeling of linguistic insecurity as a non-native speaker, produced phrases such as "I'm going to try [to tell]", "I can tell [my story]", "I'm going to stop [talking]", "I can continue [to talk]", "how do you say?", while Leila said at one point, "I'm going to talk about something rather funny". All these discursive indicators, or phatic utterances, seem to reflect the narrators' ability not only to highlight their own narrative activity, but also to encourage their interlocutors to actively listen, creating with them a social and emotional link in this specific learning language setting (Ducrot \& Schaeffer, 1995).

We drew three main observations from this third analysis:

a) The participants presented themselves as active agents of their life, strong and autonomous women, who were able to make decisions, mobilize resources and to find solutions;

b) They also demonstrated their ability to contribute to the complex discursive activity of narration. This involved the use of various linguistic strategies (alternation between active and generic forms of the verbs, indirect discourse, etc.) to construct coherent and reflexive narratives, in which the self of the narrator who was narrating, the self of the actor who was narrated and the interlocutors were interlinked;

c) In constructing their narratives, the narrators evoked absent persons and constructed dialogues with them. By so doing, they created a cast of characters who brought their stories to life and wove links between the present and the past, the here and there.

\section{Conclusion}

The experience of migration often brings with it feelings of separation, and affects migrants' sense of agency, particularly in a political and historical context where they are perceived of as having few or no resources. In sociocultural research on identity, narration (especially self-narration) is seen as a powerful cultural tool for making sense of personal experience and producing agency (Bruner, 2006; Daiute \& Kreniske, 2016). The purpose of the present study was twofold: to design an intervention allowing migrant women to recount their personal stories and express their resources in a context where they are generally expected to stay silent; and to improve current understanding the processes of self-narrative and agency construction in this setting.

Adopting an interactionist stance on narrative, whereby a self-narrative results from a process of co-construction involving other participants (Bamberg, 2011; Goodwin, 2015), we focused on the interactional procedures of narration. The methods of analysis were chosen for their potential to highlight the collective production of NDUs, and to provide information about the interactional and collective processes of framing participants' self-narratives and displaying agentic relationships.

Fine-grained analysis of three self-narratives yielded the following findings.

We showed that each NDU emerged from the participants' work of negotiating their respective positions in a space that was generally opened up by a question-response pattern or an adjacency pair. Before taking the floor as the sole narrator, each interlocutor participated in a collective prefatory phase. This served to construct her role and designate her as the legitimized speaker (speaker authorised to talk, ratified speaker, and performant speaker - despite some language gaps).

In this interactional analysis, we also showed how each narrative was woven not only by the other participants' discursive actions (e.g., questions) during the ongoing storytelling activity, but also by the voices of people who were not present, such as those whose stories had been told earlier in the session, the fictional figures of tales such as Heidi, or even family members (e.g., husband or children), who served as resources in the narrative activity.

We believe that this finding can be related to another result of the analysis regarding the interactive construction of each selfnarrative. This analysis highlighted the agentic relationships the narrators constructed in their stories. All three participants presented themselves as being proactive and taking charge of their lives, even in difficult times. The analysis of specific discursive elements, 
such as the active versus passive forms of the verbs used, the genericity modality of describing the events indicating the enunciatory absence of the narrator from the events being recounted, and the reflexive remarks about their own discourse, revealed two interesting aspects of agency in the narrative activity. First, we observed that the narrators presented themselves in their narratives as active agents able to take decisions, carry out clear actions, and achieve risky solutions. Second, analysis revealed that the women were capable of being active and reflexive speakers in the current narrating activity, using discursive resources to structure their narratives, displaying the temporal sequences, choosing and developing topics and placing the drama at the core of their story. They were also seen to emotionally engage their audience. Here, this dual agency dramatically challenged the image of poor immigrant women with no physical, financial or linguistic resources that is often portrayed in the mass media.

The general framing of the intervention promoted the elaboration of this agentic image. This framing was designed to be benevolent and to allow the participants to build their personal stories across four sessions, based on the structure of other collective tales in which a hero figure is given a central role, with a view to including them in a collective production (i.e., booklet). All these elements can be seen as ingredients of the collective and agentic construction of a self-narrative and the delicate operation of reframing personal experiences.

These findings led to think about how future research could help to further understand and support the development of immigrants' narratives. The role of the formal elements that allowed the NDUs to be produced by the participants (who generally faced the problem of linguistic insecurity when they arrived in this new context), as well as the agency process fostered by the discursive circulation of the narratives among the participants, appear to be key. Adopting a resolutely interactional perspective, we regarded these elements as being closely intertwined.

The present study can be regarded as a first step towards a better understanding of the interactional processes of constructing selfnarratives and the conditions for sustaining individuals exposed to vulnerability. Further research should be undertaken, in particular to examine other dimensions that the design of our study prevented us from exploring, which can be regarded as a limitation. In particular, we failed to take account of the participants' gestures and the way they embodied the activity of narrative co-construction (Goodwin, 2015).

According to the theoretical and methodological perspective we adopted, narrative is not only a means of communication used by a single narrator to describe past events, but also and above all a cultural and psychological instrument that allows experiences to be constructed and reconfigured for others, with others, and for oneself. This approach combining a practical intervention with research on narratives is particularly relevant for thinking about the collective conditions that allow people to draw on their resources in order to overcome the obstacles associated with transitions such as migration.

\section{Acknowledgments}

The authors are very grateful to all the women who agreed to participate to the intervention and to the teacher who accurately contributed to the reflexion and the development of the intervention. They warmly thank the young researchers who participated to the process of designing and implementing. They also would like to thank Elizabeth Portier for her precious help with the English language. This research did not receive any specific grant from funding agencies in the public, commercial, or not-for-profit sectors.

\section{Declaration of interest}

None.

Appendix A. Norms of transcription (from ICAR, 2013)

\begin{tabular}{ll}
\hline & Sudden interruption \\
$<\ldots>$ & Uncertain transcription \\
{$[\ldots]$} & Overlapping \\
$=$ & Immediate sequencing \\
$((\ldots))$ & Transcriber's comment \\
XXX & Incomprehensible segment, each X correspond to a syllable \\
CAPITALS & Louder syllable \\
$::$ & Stretching of a syllable. The number of: depends on the duration of the stretching \\
$()$. & Falling intonation \\
, & Slightly falling intonation \\
\hline & Pause of half a second \\
\hline
\end{tabular}


Appendix B. Excerpts in original French language

\section{Excerpt 1.}

\section{Excerpt 1}

$\begin{array}{ll}1 & \text { Marcelo } \\ 2 & \text { Tous } \\ 3 & \text { Leila } \\ 4 & \text { Marcelo } \\ 5 & \text { Tracy } \\ 6 & \text { Marcelo } \\ 7 & \text { Tracy } \\ 8 & \text { Colomba } \\ 9 & \text { Tracy } \\ 10 & \text { Leila } \\ 11 & \text { Tracy } \\ 12 & \text { Marcelo } \\ 13 & \text { Nathalie } \\ 14 & \text { Marcelo } \\ 15 & \text { Leila }\end{array}$

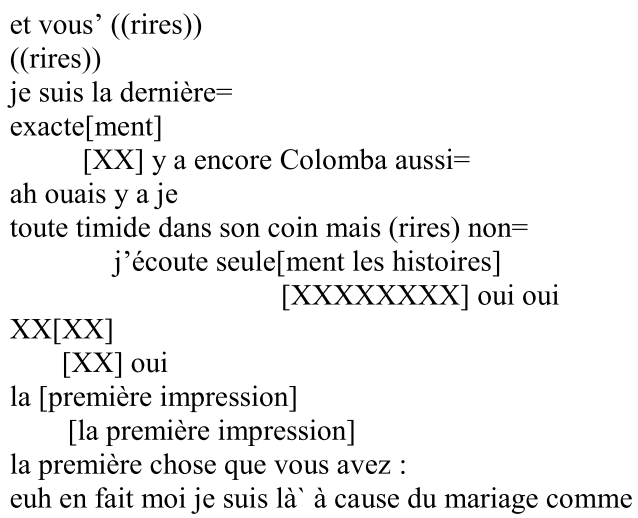

\section{Excerpt 2.}

\section{Excerpt 2}

1 Iliana mais peut-être une chose c'est c'est peut-être pas gentil de demander mais pourquoi pourquoi vous êtes venue ici' / je crois que c'est c'est une question=

$\begin{array}{lll}2 & \text { Tracy } & \text { importante' } \\ 3 & \text { Iliana } & \text { pour le passage } \\ 4 & \text { Tracy } & \text { oui pourquoi en vient en Suisse' }\end{array}$

4 Tracy oui pourquoi en vient en Suisse'

5 Iliana pour écrire une histoire mais normalement on sait ce qui s'est passé avant / comme Heidi on sait qu'elle était dans la montagne ((rires)) J'AIMERAIS SAVOIR si tu nous veux dire / parce que je crois pour nous il y a vraiment des histoires très fortes et voilà c'est un peu euh : on n'est pas obligé de dire' ouais MAIS peut-être ça peut être sympa pour nous de savoir qu'est-ce qu'elle faisait dans euh : avant (rires) voilà / parce [que sinon sinon]
6
Kaja
[oui je peux dire]

\section{Excerpt 3.}

\section{Excerpt 3}

1 Kaja Oui heu je peux dire, mais j'ai pas confiance dans ma langue qui

2 Iliana ouais je sais

3 Kaja est pas bien bien mais je vais essayer. Heu je viens à cause de politique

4 Iliana ouais

5 Kaja heu je suis Kurde, Kurde et pour vivre en Turquie c'est très très difficile' Et pis heu notre famille ils sont en prison ::: tués l'histoire qu'on est passé :: et pis mon mari il est resté dans la prison neuf ans heu ((soupir-ému))

\section{Iliana voilà non mais}

7 Kaja quand il sorti et pis heu je vais arrêter

8 Iliana non non mais je veux pas voilà, on comprend mais, on sait que t'as grand chose dedans ((Kaja ouais ouais)) on voit dans les yeux c'est pour ça que ::: voilà, c'est bon comme ça :: Y A PAS besoin de dire (rires) je crois c'est comme ça

$9 \quad$ Marcelo Merci en tout cas ((oui oui)) c'est un c'est tu nous fais confiance merci

\section{Excerpt 4.}

\section{Excerpt 4}

1 Kaja oui oui et puis je suis passé une année c'est trop difficile avec mes deux enfants parce que je connaître pas personne euh : ouais

2 Iliana nous avons trouvé l'héroïne de l'histoire c'est une vraie héroïne

3 Tous ((rires))

$4 \quad$ Iliana tu es très courageuse 


\section{Excerpt 5.}

\section{Excerpt 5}

1 Marcelo et quelle est la- quelle était la première la première chose que vous avez remarqué en Suisse, la première impre[ssion que ça soit physique]

2 Leila [première fois j'ai vu] un beau pays`

3 Marcelo hum

4 Leila mais/ qui est tout froid' c'est-à-dire pas de sentiments,

$5 \quad$ Marcelo AH [froid dans ce sens']

$6 \quad$ Leila

sont occupés de toi $=$

7 Marcelo hum $=$

8 Leila de gens qui vous aident`si vous êtes malade` tout est triste` parce que nous` chez nous`on a habitué toujours`à des familles qui sont beaucoup approchées XX/

\section{Excerpt 6.}

\section{Excerpt 6}

$1 \quad$ Iliana et puis moi aussi' j'ai senti beaucoup de froid' je me rappelle même pas' le froid que c'était moche, / pas bien, mais' un air frisant' je sais pas,

2 Marcelo hum hum

3 Iliana c'était différent' de l'air que j'étais habitué à sentir' / là je me rappelle beaucoup' de ça, de ce sentiment-là' après je suis arrivée je comme- j'avais déjà connu la Suisse' j'avais des bons souvenirs' alors euh: voilà' j'étais tout positive' mais / l'air froid comme ça' ((rires)) ouais c'est différent' là XXX beaucoup ouais

\section{Excerpt 7.}

\section{Excerpt 7}

Kaja oui oui en arrivant. Oui là heu :: on vivre c'est trop dramatique je suis neuf ans j'ai allé toujours la porte de la prison, toujours avec mes enfants, j'ai travaillé, et pis je cachais toujours moi aussi, je cachais de police, toujours j'ai vivre des problèmes politiques, et pis dans Istanbul toujours je changeais de appartement, parce que c'est trop difficile

\section{Excerpt 8.}

\section{Excerpt 8}

Iliana la voiture' avait vraiment à la sicilienne' j'ai mis tout dedans' ((rires)) je me suis dit: là j'ai eu peur / parce que je suis partie de ((mon pays)) avec deux petits' avec moi' et toute la voiture pleine comme ça' / ça ça me faisait mal' parce que *oh* ( ${ }^{*}$ changement d'intonation)) qu'elle me regarde avec toutes ces choses comme ça' et m'arrête là' et après voilà'

\section{Excerpt 9.}

\section{Excerpt 9}

Leila j'ai resté deux mois` là-bas`mais j’ai trouvé euh toute ma vie ch- est changer j'ai quitté la maison de mes parents`j'ai quitté travail’ j'ai quitté : euh ma capital (...) comme j'ai quitté tous pourquoi pas la Suisse et commencer de nouveau' comme ça découvrir quelque chose et je suis venue ici (rires)

\section{Excerpt 10.}

\section{Excerpt 10}

Iliana j'ai dit *alors tu es prêt'*il m'a dit *oui ok* 


\section{References}

Antaki, C., \& Widdicombe (Eds.). (1998). Identities in talk. London: Sage.

Bruner, J. (1990). Acts of meaning. Massachusetts, USA: Harvard University Press.

Bruner, J. (2003). Making stories: Law, literature, life. Massachusetts, USA: Harvard University Press.

Bruner, J. (2006). Life as narrative. Social Research, 71(3), 691-711.

Bamberg, M. G. (Ed.). (1997). Narrative development: Six approaches. Mahwah, USA: Lawrence Erlbaum Publishers.

Bamberg, M. (2004). Narrative discourse and identities. In J. C. Meister, T. Kindt, W. Schernus, \& M. Stein (Eds.). Narratology beyond literary criticism (pp. 213-237). Berlin, New York: Walter de Gruyter.

Bamberg, M. (2011). Who am I? Narration and its contribution to self and identity. Theory \& Psychology, 21(1), 3-24. https://doi.org/10.1177/0959354309355852.

Bhatia, S., \& Ram, A. (2001). Rethinking "acculturation" in relation to diasporic cultures and postcolonial identities. Human Development, 44, 1-18.

Bhatia, S., \& Ram, A. (2004). Culture, hybridity, and the dialogical self: Cases from the South Asian diaspora. Mind, Culture, and Activity, 11(3), 224-240. https://doi. org/10.1207/s15327884mca1103_4.

Daiute, C., \& Kreniske, P. (2016). Hopes, misunderstandings and possibilities of narrating for inclusive education. In A. Surian (Ed.). Proceedings of open spaces for interaction and learning diversities. Rotterdam, The Netherlands: Sense Publishers.

De Abreu, G., O'Sullivan-Lago, R., \& Hale, H. C. (2012). "Nowadays I think, "Wow: I made it”". Exploring immigrant transitions drawing on dialogical self theory and the notion of symbolic resources. In B. Ligorio, \& M. César (Eds.). Interplays between dialogical learning and dialogical self (pp. 127-150). Charlotte, USA: Information Age Publishing.

Ducrot, O., \& Schaeffer, J.-M. (1995). Nouveau dictionnaire encyclopédique des sciences du langage, avec la collaboration de Marielle Abrioux, Dominique Bassano, Georges Boulakia, Michel Fornel, Philippe Roussin et Tzvetan Todorov. Paris, France: Seuil.

Gardner, R., \& Wagner, J. (2004). Second language conversations. New York: Continuum.

Garfinkel, H. (1967). Studies in ethnomethodology. Englewood Cliffs, New Jersey, EUA: Prentice Hall.

Goodwin, C. (2015). Narrative as talk-in-interaction. In A. de Fina, \& A. Georgakopoulou (Eds.). The handbook of narrative analysis (pp. 195-218). London: John Wiley \& Sons.

Greco Morasso, S. (2013). Multivoiced decisions: A study of migrants' inner dialogue and its connection to social argumentation. Pragmatics \& Cognition, 21(1), 55-80. https://doi.org/10.1075/pc.21.1.03mor.

Greco Morasso, S., \& Zittoun, T. (2014). The trajectory of food as a symbolic resource for international migrants. Outlines, 15(1), 24-48.

Grossen, M. (2015). The diary as a dialogical space. In B. Wagoner, N. Chaudhary, \& P. Hviid (Eds.). Integrating experiences: Body and mind moving between contexts (pp. 201-219). Charlotte, USA: Information Age Publishing.

Goodwin, C. (1984). Notes on story structure and the organization of participation. In M. Atkinson, \& J. Heritage (Eds.). Structures of social action (pp. 225-246). Cambridge: Cambridge University Press.

Gülich, E., \& Quasthoff, U. M. (1985). Dimensions of discourse. In T. A. van Dijk (Ed.). Handbook of discourse analysis (pp. 169-192). London: Academic Press.

Heritage, J. (2013). Garfinkel and ethnomethodology. New York, USA: John Wiley \& Sons.

Hermans, H. J. M. (2001). The dialogical self: Toward a theory of personal and cultural positioning. Culture \& Psychology, 7(3), 243-281. https://doi.org/10.1177/ 1354067 X0173001.

Hermans, H., \& Kempen, H. (1998). Moving cultures. The perilous problems of cultural dichotomies in a globalizing society. American Psychologist, 53(10), 1111-1120. Holland, D. C., \& Valsiner, J. (1988). Cognition, symbols and Vygotsky's developmental psychology. Ethos, 16(3), 247-272.

ICAR (2013). Convention ICOR. Lyon: University of Lyon 2. http://icar.cnrs.fr/projets/corinte/documents/2013_Conv_ICOR_250313.pdf.

Kofler, A. C., Fankhauser, L., \& Zweifel, C. (2009). Femmes en migration: l'image des migrantes dans la perception de l'opinion publique et de la politique, ainsi que dans la recherche actuelle. Berne, Suisse: Commission fédérale pour les questions de migration (CFM).

Mäkitalo, A. (2016). On the notion of agency in studies of interaction and learning. Learning, Culture and Social Interaction, $10,64-67$.

Muller Mirza, N., Grossen, M., de Diesbach-Dolder, S., \& Nicollin, L. (2014). Transforming personal experience and emotions through education to cultural diversity: An interplay between unicity and genericity. Learning, Culture and Interaction, 3(4), 263-273. https://doi.org/10.1016/j.lcsi.2014.02.004.

Pekarek Doehler, S. (2013). Conversation analysis and second language acquisition: CA-SLA. In C. A. Chapelle (Ed.). The encyclopedia of applied linguistics (pp. 1-7). Oxford, UK: Blackwell Publishing Ltd. https://doi.org/10.1002/9781405198431.wbeal0217.

Pekarek Doehler, S. (2006). Compétence et langage en action. Bulletin Suisse de Linguistique Appliquée, VALS-ASLA, 84, 9-45.

Rajala, A., Martin, J., \& Kumpulainen, K. (2016). Agency and learning: Researching agency in educational interactions. Learning, Culture and Social Interaction, 10, 1-3. Rosa, C., \& Tavares, S. (2013). Grasping the dialogical nature of acculturation. Culture \& Psychology, 19(2), 273-288. https://doi.org/10.1177/1354067X13478987. Schegloff, E. A. (1968). Sequencing in conversational openings. American Anthropologist, 70(6), 1075-1095. https://doi.org/10.1525/aa.1968.70.6.02a00030.

Schegloff, E. A. (1972). Notes on a conversational practice: Formulating place. In D. Sudnow (Ed.). Studies in social interaction (pp. 75-119). New York: Free Press.

Schegloff, E. A. (1992). On talk and its institutional occasions. In P. Drew, \& J. Heritage (Eds.). Talk at work: Interaction in institutional settings (pp. 101-134). Cambridge: Cambridge University Press.

Schegloff, E. A., \& Sacks, H. (1973). Opening up closings. Semiotica, 8(4), 289-327.

Van Dijk, T. A. (1995). Ideological discourse analysis. New Courant, 4, 135-161.

Vygotsky, L. S. (1978). Mind in society: The development of higher psychological processes. Cambridge, UK: Harvard University Press.

Wertsch, J. V. (1985). Culture, communication, and cognition: Vygotskian perspectives. Cambridge, UK: Cambridge University Press.

Wertsch, J. V. (2000). Intersubjectivity and alterity in human communication. In I. C. Uzgiris, \& J. V. Wertsch (Eds.). Communication: An arena of development (pp. 1731). Westport, Ireland: Ablex Publishing.

Xenitidou, M., \& Greco Morasso, S. (2013). Parental discourse and identity management in the talk of indigenous and migrant speakers. Discourse \& Society, 25(1), 100-121. https://doi.org/10.1177/0957926513508858.

Zittoun, T., Gillespie, A., Cornish, F., \& Aveling, E.-L. (2008). Using social knowledge: A case study of diarist's meaning during World War II. In T. Sugiman, K. Gergen, \& W. Wagner (Eds.). Meaning in action: Construction, narrative and representation (pp. 163-179). Tokyo: Springer.

Nathalie Muller Mirza is assistant professor at the University of Lausanne, Switzerland. Her main research interest focuses on identity processes in the contexts of education, in a cultural-historical perspective that integrates the constitutive role of social interactions and culture in learning. Her main research concerns identity processes of migrants or people experiencing transitions into a new learning environment and the role of social interactions in educational settings.

Marcelo Dos Santos Mamed is graduate assistant and $\mathrm{PhD}$ candidate at the University of Lausanne, Switzerland. His main research interest focuses on linguistic processes, in a cultural-historical perspective that integrates the constitutive role of social interactions in teaching-learning context. His thesis concerns explanation processes between caregivers and diabetic patients in the context of therapeutic patient education. 